\title{
INVESTGGACJÓN
}

\section{The contents of sesamol and related lignans in sesame, tahina and halva as determined by a newly developed polarographic and stripping voltametric analysis}

\author{
By Ozlem Tokusoglu, ${ }^{* 1}$ Süleyman Koçak, ${ }^{2}$ and Sule Aycan ${ }^{3}$
}

\author{
${ }^{1}$ Celal Bayar University, Akhisar M.Y.O.,45200, Akhisar, Manisa,Turkey; \\ ${ }^{2}$ Ege University, Department of Chemistry, 35100, Bornova, Izmir, Turkey; \\ ${ }^{3} \mathrm{Mu}$ la University, Faculty of Educ. Department of Chemistry, Mu la, Turkey. \\ ( ${ }^{\star}$ Corresponding author: otokusoglu @ superonline.com)
}

\section{RESUMEN}

Contenido de sesamol en sésamo, tahina, y halva por un nuevo método de análisis polarográfico y voltamétrico.

Se determinó el contenido del lignano antioxidante (Sesamol) en sésamo, formulaciones comerciales de tahina y halva, que es el producto procesado de tahina, por polarografía de pulsos diferencial (DPP) con un capilar conteniendo un electrodo de gota de mercurio (HMDE). Un hilo de platino fué usado como el electrodo contador y $\mathrm{Ag} / \mathrm{AgCl}$ como electrodo de referencia. Las muestras fueron analizadas por procedimientos de adición de patrones y se encontró que wl procedimiento era cuantitativo $(p<0.01)$. Debido a que el sesamol es un compuesto fenólico soluble en aceite, se estudiaron los porcentajes de aceite en sésamo, tahina y halva. Las muestras de sésamo contenían un 51.05-56.46 \% de aceite mientras que la muestras de tahina tenían un 52.12$53.79 \%$ de aceite. Se encontró que el porcentaje de aceite de halva fue un $28.79-30.13 \%(p<0.01)$. El sesamol encontrado en el sésamo fue de $0.26-0.32 \mathrm{mg} / 100 \mathrm{~g}$ de aceite, mientras que el sesamol en tahina fue de 10.98-12.33 $\mathrm{mg} / 100 \mathrm{~g}$ de aceite. El sesamol de muestra de halva de procedencia comercial diferente varió entre 8.24-9.12 mg/100 g de aceite y $4.97 \mathrm{mg}$ sesamol/100 g de aceite, respectivamente $(R 2=0.9999)(p<0.01)$. El método polarográfico propuesto (DPP) es un método rápido y reproducible para la determinación simultánea de lignanos fenólicos en sésamo y otros productos alimentarios que contienen sésamo. Éste proporciona una detección cuantitativa adecuada y sensible de este compuesto nutraceútico en alimentos comerciales.

PALABRAS CLAVE: Halva - Lignanos - Polarografía Sésamo - Tahina - Voltametría.

\section{SUMMARY}

The contents of sesamol and related lignans in sesame, tahina and halva as determined by a newly developed polarographic and stripping voltammetric analysis.

The contents of antioxidant lignans (Sesamol) in sesame, commercial formulations of tahina and halva, which are processed tahina foods, were determined by Differential
Pulse Polarography (DPP) with a capillary hanging mercury drop electrode (HMDE). A platinum wire was used as the counter electrode and $\mathrm{Ag} / \mathrm{AgCl}$ was the reference electrode. Samples have been analyzed by standard addition procedures and found to be quantitative $(p<0.01)$. Due to the fact that sesamo is an oil-soluble phenolic compound, it was found in the oil levels of sesame, tahina and halvas. Sesame samples contained $51.05-56.46 \%$ in oil whereas tahina samples contained $52.12-53.79 \%$ in oil. The oil percentage of plain halva was found to be $28.79-30.13 \%(p<0.01)$. Phenolic lignan sesamol in sesame was $0.26-0.32 \mathrm{mg} / 100 \mathrm{~g}$ oil, whereas the sesamol in tahina was $10.98-12.33 \mathrm{mg} / 100 \mathrm{~g}$ oil. The sesamol in commercial plain halva samples and the open marketed plain halva samples contained 8.24-9.12 $\mathrm{mg} / 100 \mathrm{~g}$ oil and $4.97 \mathrm{mg}$ sesamol $/ 100 \mathrm{~g}$ oil, respectively $\left(R^{2}=0.9999\right) \quad(p<0.01)$. The proposed Differential Pulse Polarographic (DPP) method is a rapid, reproducible procedure for the simultaneous determination of phenolic lignans in sesame and food products with sesame. It provides an adequate, sensitive, quantitative detection of these nutraceuticals in the commercial food industry.

KEY-WORDS: Halva - Lignan compounds Polarography - Sesame - Tahina - Voltammetry.

\section{INTRODUCTION}

The sesame seed (Sesamum Indicum L.) is a valuable oil crop in Turkey. In 1998, Turkey's annual production was 33.500 metric tons and it was the fifth oilseed in the agricultural field after cottonseed, sunflower, soy, and peanut (Tokusoglu et al., 2004a; 2003a,b; Anonymous, 1999). Sesame seeds are mainly cultivated in the Aegean ("Ege"), Mediterranean ("Akdeniz") area and the GAP area in the eastern part $t$ of Turkey. 5 varieties of sesame seeds are cultivated: $59 \%$ brown, $30 \%$ yellow, $13 \%$ white, $7 \%$ dark-brown and $1 \%$ black (Tokusoglu et. al, 2004). Sesame seeds are used in the baking industry, for the production of tahina (sesame paste), in the manufacturing of a sweet meat called "halva", as a spice mixture and specialty gourmet oil in addition to its application in soap, cosmetics, 
pharmaceuticals and by-product industries (Tokusoglu et. al, 2003 a,b).

Sesame seed oil is unique due to its unusually high oxidative stability as compared to other edible oils (Budowski, 1962; Kamal-Eldin et al.,1994). This strong antioxidant activity has been attributed mainly to the presence of $\gamma$-tocopherol and antioxidative sesame lignans such as sesamin, sesamolin and sesamol (Tokusoglu et. al, 2003 a,b; Yoshida et al.,1995; Yoshida and Takagi,1998).

Sesame oil contains important antioxidants, sesamolin and sesamol, that are believed to promote the integrity of body tissues in the presence of oxidizing compounds. Sesame oil is rich in polyunsaturated fatty acids (PUFAs) which are known to reduce harmful (LDL) cholesterol and prevent the oxidation of fats in the blood vessels. Sesame seed oil contains calcium, an important nutrient for the entire vascular system. In vitro studies showed that sesame oil also protects the body against skin and colon cancer and produces anti inflammatory effects (Sahelian, 2007). Sesame seed oil is naturally antimicrobial for common skin pathogens, such as Staphylococcus spp. and Streptococcus spp. as well as common skin fungi, such as athlete's foot fungus. It has a unique ability to penetrate the skin easily, nourishing and detoxifying even the deepest tissue layers (Sahelian, 2007).

Tocopherols and lignans as sesame seed oil constituents have been reported to be unsaponifiable matters (Tokusoglu et. al, 2003 a; Yoshida and Takagi,1998; Mohamed and Awatif, 1998). Tokusoglu et. al (2003 a) reported tocopherols such as $\gamma$-tocopherol and the minor homologues $\alpha$-and $\delta$-tocopherol in 14 species of sesame seed oils in Turkey. The $\gamma$-tocopherol content in sesame seeds varied from 793.0 to $1330.0 \mathrm{mg} \mathrm{kg}$ ${ }^{1}(p<0.01)$ whereas seeds contained $1.9-5.1 \mathrm{mg} \mathrm{kg}^{-1}$ of $\alpha$-tocopherol and $0.5-0.6 \mathrm{mg} \mathrm{kg}^{-1}$ of $\delta$ - tocopherol $(p<0.01)$ and according to that study which examined 3 different roasting conditions, the optimal roasting conditions were $5 \mathrm{~min}$ at $220^{\circ} \mathrm{C}(p<0.01)$ and the levels of gamma $(\gamma-)$ tocopherol remained in over $95 \%$ of the original amounts in Turkish sesame seeds (Tokusoglu et. al, 2003 a).

Sesamol (3, 4-Methylenedioxyphenol) $\left(\mathrm{C}_{7} \mathrm{H}_{6} \mathrm{O}_{3}\right)$ (Figure 1) has been generally regarded as the main antioxidative component in sesame seeds (Fukuda et al.,1981). Sesame oil is characterized by the presence of a number of compounds from the furofuran family, mainly sesamin and sesamolin (Kamal-Eldin and Appelqvist, 1994; Kamal-Eldin et al., 1994).

Lignan compounds and lignan glycosides present in sesame are important functional components. The main sesame lignans, sesamin and sesamolin in sesame oil, possess no antioxidative activity but sesamol, sesaminol and sesamol dimmers are reported as possibly strong antioxidants and as playing an important role in the oxidative stability of sesame oil. During sesame oil manufacturing sesamolin can be converted to other lignans containing sesamol, sesaminol and sesamol dimmers (Kamal-Eldin and Appelqvist, 1994; Tokusoglu, 2005). Sesamol exhibits antimutagenic activity against oxygen species mediated mutagenicity (Kaur and Saini, 2000).

Recently, there has been increasing interest in nutraceuticals in dietary foods due to their protective biochemical functions and antioxidant effects. Amarowicz et. al.(2001) reported the application of semipreparative RP-18 HPLC for the purification of the furofuran lignans sesamin and sesamolin in sesame seed oil by rechromatography using an analytical HPLC and GC-MS. The antioxidant activity of the crude extract of lignan glycosides from the unroasted Burma black sesame meal has also been reported (Shyu and Hwang, 2002). Sesame lignan aglycons (sesaminol, sesamol, sesamolin and sesamin) (Figure 1.) in tahina (sesame paste) were determined using a rapid GC procedure by Tokusoglu et al. (2004c).

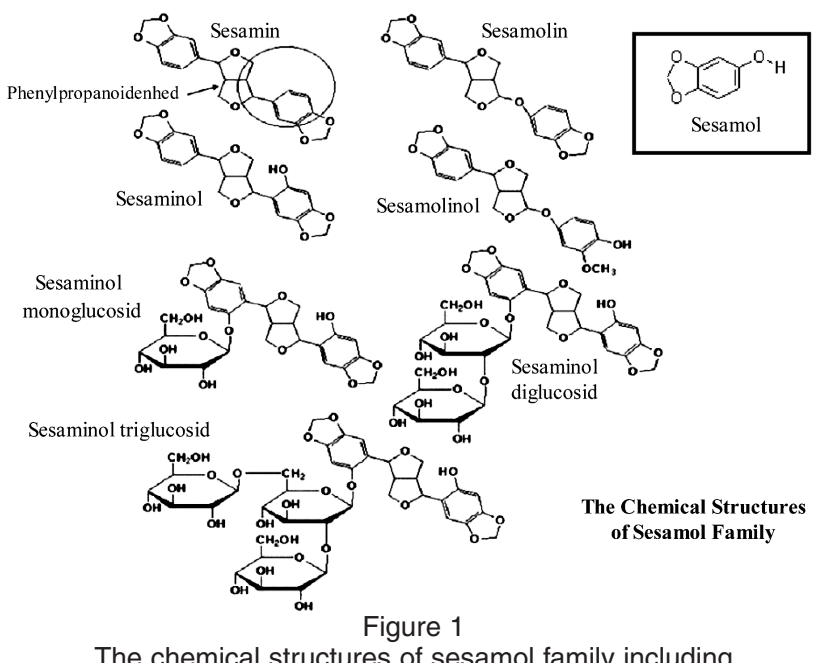

The chemical structures of sesamol family including sesame lignan

The need for regular monitoring of lignan nutraceuticals in sesame-based food products and relevant foods has led to an increasing demand for adequately sensitive and selective analytical techniques with low-cost determination capabilities. Differential Pulse Polarography (DPP), which is a voltammetric technique, has become accepted as one the most powerful electroanalytical tools for the microelement analysis of food and biological matrices owing to its extreme sensitivity and selectivity (Koçak et al., 2005; Tokusoglu et al, 2004b; Aycan et al., 2003; Li-Qiong et al., 1999; Rodrigues et al., 1999; Aycan, 1994).

No study could be found concerning effective Differential Pulse Polarographic (DPP) methods for the determination of lignan compounds in sesame and sesame-based products.

The objective of this study was to determine the sesamol and related lignan compounds in sesame, tahina and halva by DPP and to propose new methods concerning the determination of sesamol 
and related lignans by Differential Pulse Polarography (DPP).

\section{MATERIALS AND METHODS}

\subsection{Research Material}

3 brown sesame seed genotypes [Gölmarmara (Menemen), Muganls (Menemen), Özberk (Ege Univ.)] were obtained from the Ege Agricultural Research Institute, Menemen, Izmir, Turkey and the Dept. of Field Crops of Ege University Bornova, Izmir,Turkey. Tahina (sesame paste) and plain halva materials were obtained from "Koska A.fi.", Istanbul,Turkey, "Ömer Befle A.fi., Izmir, Turkey"and "Manisali G> da A.fi.", in April, 2003. 3 jars of the same brand of tahina samples and 3 different homogeneous parts of the same kind of tahina were used for the analysis $(n=9)$. 3 packaged halva samples and 3 different homogeneous parts of the same kind of halva were analyzed $(n=9)$. Each was analyzed in duplicate.

\subsection{Sample Preparation}

\section{Proximate Analysis}

The moisture content of $5.0 \mathrm{~g}$ samples was determined at $110^{\circ} \mathrm{C}$ for $24 \mathrm{~h}$ in an oven using the procedure described by AOAC (1999).

The total lipids of sesame, tahina, and halva were determined by a reported method regarding sesame lipids from Tokusoglu et al. (2003a). $15 \mathrm{~g}$ of sample were homogenized in a homemade homogenizer with $45 \mathrm{~mL}$ of chloroform/ methanol $(2: 1 \mathrm{v} / \mathrm{v})$ at $0^{\circ} \mathrm{C}$ and then mixed using a vortex for 30 s. Homogenized samples were centrifuged at $4000 \mathrm{rpm}$ for $15 \mathrm{~min}$. The chloroform phase including the extracted lipids was transferred and the residue was extracted three more times using the same procedure and then filtered through lipid-free filter paper. The combined filtrates were concentrated in a rotary evaporator at $30^{\circ} \mathrm{C}$ under reduced pressure and evaporated using an $\mathrm{N}_{2}$ flow to dryness. After drying over anhydrous sodium sulphate $\left(\mathrm{Na}_{2} \mathrm{SO}_{4}\right)$, final extracts were stored in chloroform/methanol $(2: 1 \mathrm{v} / \mathrm{v})$ solutions kept in screw cap containers, in the dark and at $-28^{\circ} \mathrm{C}$ until needed.

\section{Electroanalytical determination for Sesamol Analysis}

For Differential Pulse Polarographic Analysis; A polarographic analyzer (METROHM 746 VA Trace Analyzer) together with a capillary hanging mercury drop electrode (HMDE) and Lenseis LY 1600 Model recorder was used for all electroanalytical measurements.A platinum wire was used as the counter electrode and $\mathrm{Ag} / \mathrm{AgCl}$ was used as the reference electrode.

The Sesamol analysis was confirmed by the official method of AOCS concerning the phenolic antioxidants of sesame oil (AOCS,1998). DPP method validation was also performed with the standard reference method AOCS Method $\mathrm{No}: \mathrm{Cb}$ 2-40 (1998).

\subsection{DPP Analysis}

For the quantitative determination of the lignan sesamol, the polarogram of the sesamol in the standard mix solution was obtained using the standard addition procedure. For the sample analysis, $100 \mathrm{ppm}$ of sesamol standard solution were prepared daily. A trial electrode system was used including HMDE (Hanging Mercury Drop Electrode) as the working electrode, $\mathrm{Ag} / \mathrm{AgCl}$ (saturated $\mathrm{KCl}$ ) as the reference electrode and $\mathrm{Pt}$ electrode as the support electrode. For sesamol analysis, $1.00 \mathrm{ml}$ $(0.1 \mathrm{M})$ of tetramethylamoniumhydroxide was used as the support electrolide solution in the Pyrexpolarographic cell. $1 \mathrm{ml}$ of sample was added to $10 \mathrm{~mL}$ of ethyl alcohol including $1 \mathrm{~mL}(0.1 \mathrm{M})$ of tetramethylamoniumhydroxide $\left(\mathrm{Me}_{4} \mathrm{NH}_{4} \mathrm{OH}\right)$ electrolide solution. The cell contents were deaerated by passing pure nitrogen $\left(\mathrm{N}_{2}\right)$ gas $(99.999 \%)$ for about 300s at a flow rate of $100 \mathrm{ml} / \mathrm{min}$ to obtain the inert media. For $60 \mathrm{~s}$, pre-concentration was performed and a measurement was obtained. $E_{\text {Meas }}$ : $-1650 \mathrm{mV}$ and $E_{\text {meas time }}: 60 \mathrm{~s} ; E_{\text {Start }}:-1650 \mathrm{mV}, E_{\text {End }}$ : $-2250 \mathrm{mV}, E_{\text {Peak }}:-1257 \mathrm{mV}$ and the scan velocity was $50 \mathrm{mV} / \mathrm{s}$ for the sesamol analysis. Then $1000 \mathrm{ppm}$ $100 \mu \mathrm{L}$ sesamol were added to the cell and cell contents were de-aerated for $30 \mathrm{~s}$ with $\mathrm{N}_{2}$ gas. At the same time, $1000 \mathrm{ppm} 100 \mu \mathrm{L}$ sesamol standard was added to the cell and cell contents were de-aerated for30 s with $\mathrm{N}_{2}$ gas and a measurement was obtained.Total analysis time was about $10 \mathrm{~min}$.

\section{For sesame, tahin, halva samples}

$5 \mathrm{~g}$ of sesame, tahina and halva samples were homogenized with $20 \mathrm{ml}$ of ethyl alcohol for $1 \mathrm{~h}$ in a magnetic stirrer. The homogenized solution was centrifuged at $3500 \mathrm{rpm}$ and filled to $50 \mathrm{~mL}$ with ethyl alcohol.

\subsection{Cyclic Voltammetry and Stripping Analysis}

$1 \mathrm{~mL}\left(10^{-2} \mathrm{M}\right)$ sesamol standard including $1 \mathrm{~mL}$ $(0,1 \mathrm{M})$ of tetramethylamoniumhydroxide was added to $10 \mathrm{~mL}$ of ethyl alcohol. HMDE (Hanging Mercury Drop Electrode) was used as the working electrode. The scanning velocity was $50 \mathrm{mV} / \mathrm{s}$, current height was $1.4 \mu \mathrm{A}$, scanning potential was from- $1600 \mathrm{mV}$ to $-2250 \mathrm{mV}$. Scanning was performed at this scale and anodic and cathodic peaks were obtained. If there is a positive current for the peak it is called cathodic peak, if there is a negative current for the peak it is called anodic peak. This is shown in the CV voltammogram (Figure 2). 


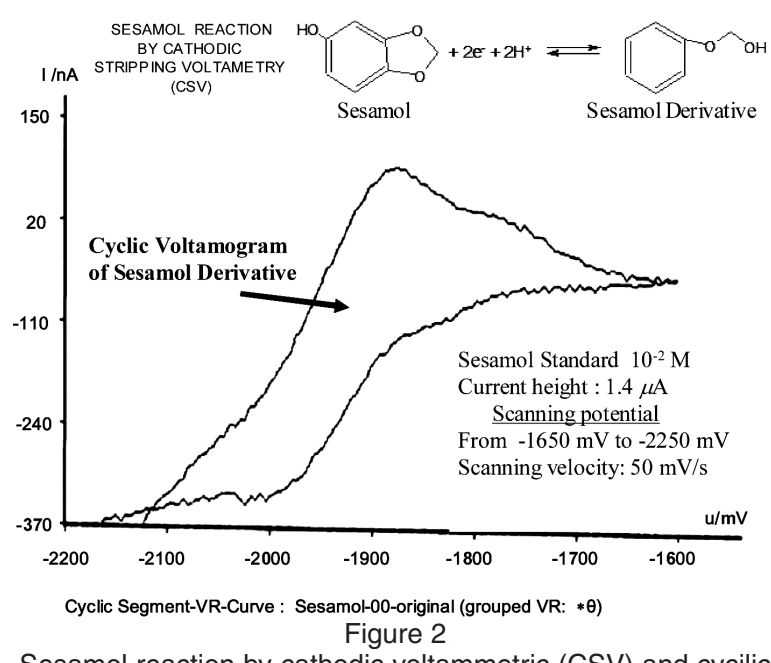

Sesamol reaction by cathodic voltammetric (CSV) and cycilic voltamogram of sesamol derivative

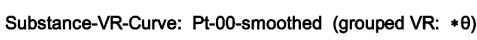

(A)

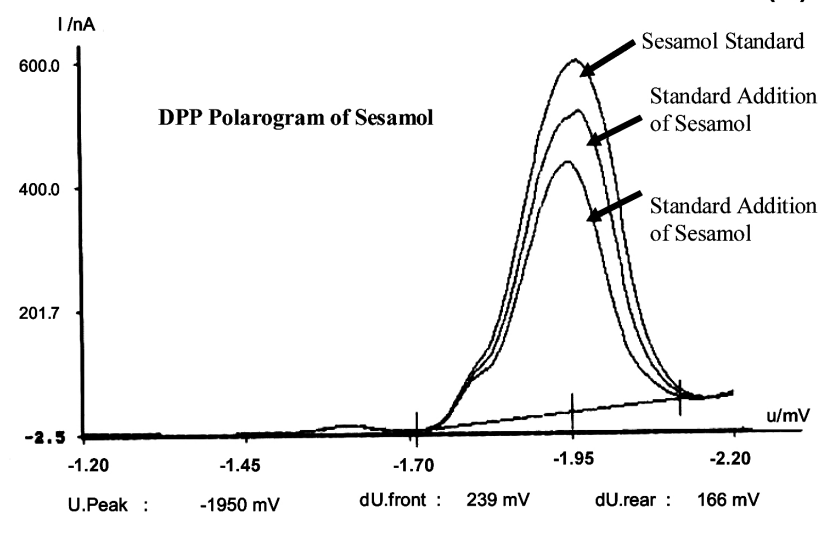

Substance-VR-Curve: Pt-00-smoothed (grouped VR: $* \theta$ )

(B)

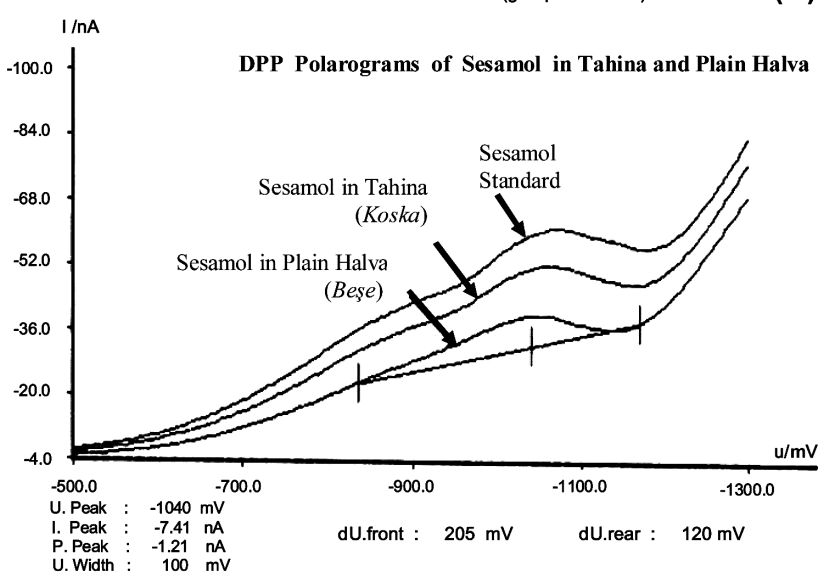

Figure 3

A. DPP polarograms of sesamol calibration

B. DPP polarograms of sesamol standard and samples

\section{RESULTS AND DISCUSSION}

A rapid electroanalytical method was developed for the identification of the nutraceutical lignan sesamol in sesame (Sesamicum Indicum $L$.), tahina and halva. Figure $3 \mathrm{~A}$ and $\mathrm{B}$ shows DPP polarograms of sesamol calibration and DPP polarograms of sesamol standard and samples [sesamol in tahina (Koska), in plain halva (Befle), respectively (Figure $3 \mathrm{~A}-\mathrm{B}$ ).

With the stripping analysis, sesamol was also perfectly separated (Figure 2). This electrochemical procedure provided for good separation of sesamol. Figure 2 shows the sesamol reaction by cathodic stripping voltammetry (CSV) and cyclic voltamogram of the sesamol derivative. With this oxidation-reduction reaction, a sesamol derivative has been formed. This reaction in cathodic stripping voltammetry included two steps. In the first step, called preconcentration, sesamol was accumulated in a solution to electrode-surface at $-1650 \mathrm{mV}$ for 60 $\mathrm{s}$; whereas in the second step, called scanning, stripping was performed from $-1650 \mathrm{mV}$ to -2250 $\mathrm{mV}$ of potential (Figure 2).

Using these electrochemical methods, sesamol was detected at $0.26-0.32 \mathrm{mg} / 100 \mathrm{~g}$ oil in three varieties of sesame $(p<0.01)$; whereas 10.98-12.33 $\mathrm{mg} / 100 \mathrm{~g}$ oil in tahina samples $(p<0.01)$ and 4.97 $9.12 \mathrm{mg} / 100 \mathrm{~g}$ oil in halva samples $(p<0.01)$ were detected. Table 1 shows the moisture and crude oil composition of sesame, tahina and halva and Table

Table 1

The moisture and crude oil composition of sesame, tahina and halva samples $(p<0.01)$

\begin{tabular}{lcc}
\hline $\begin{array}{l}\text { Sesame, Tahina and } \\
\text { Halva Samples }\end{array}$ & Moisture (\%) & Crude Oil (\%) \\
\hline $\begin{array}{l}\text { Sesame Gölm. } \\
\text { (Menem.) }\end{array}$ & $4.142 \pm 0.025$ & $56.460 \pm 0.022$ \\
\hline $\begin{array}{l}\text { Sesame Muganli } \\
\text { (Menem.) }\end{array}$ & $4.264 \pm 0.043$ & $51.053 \pm 0.041$ \\
\hline $\begin{array}{l}\text { Sesame Özberk } \\
\text { (Ege Univ.) }\end{array}$ & $4.513 \pm 0.053$ & $54.554 \pm 0.023$ \\
\hline Tahina (Koska A.fi.) & $0.403 \pm 0.022$ & $52.120 \pm 0.017$ \\
\hline Tahina (Befle A.fi.) & $0.349 \pm 0.011$ & $53.792 \pm 0.020$ \\
\hline Tahina (Manisali A.fi.) & $0.388 \pm 0.015$ & $52.123 \pm 0.024$ \\
\hline Plain Halva (Koska A.fi.) & $0.502 \pm 0.029$ & $29.235 \pm 0.010$ \\
\hline Plain Halva (Befle A.fi.) & $0.553 \pm 0.032$ & $30.137 \pm 0.026$ \\
\hline PlainHalva (ManisaliA.fi) & $0.561 \pm 0.014$ & $28.792 \pm 0.021$ \\
\hline Plain Halva (Market) & $3.746 \pm 0.030$ & $28.378 \pm 0.018$ \\
\hline
\end{tabular}

2 illustrates the sesamol levels of sesame, tahina and halva samples consumed in Turkey as determined by our suggested procedure.

Sesamol in sesame varieties occurred in the order : Muganli (Menemen) > Gölmarmara (Menemen) > Özberk (Ege University). The sesamol concentrations of tahina (Koska A.fi.) $(12.33 \pm 0.05 \mathrm{mg} / 100 \mathrm{~g}$ oil $)(p<0.01)$ and that of plain 
halva (Befle A.fi.) $(9.12 \pm 0.02 \mathrm{mg} / 100 \mathrm{~g}$ oil) were significantly higher $(p<0.01)$ (Table 2$)$.

Table 2

Sesamol concentrations in samples $(p<0.01)$

\begin{tabular}{lc}
\hline $\begin{array}{l}\text { Sesame, Tahina and Halva } \\
\text { Samples }\end{array}$ & Sesamol (mg/100g oil) \\
\hline Sesame Gölm.(Menem.) & $0.28 \pm 0.02$ \\
\hline Sesame Mug. (Menem.) & $0.32 \pm 0.05$ \\
\hline Sesame Özb. (Ege Univ.) & $0.26 \pm 0.03$ \\
\hline Tahina (Koska A.fi.) & $12.33 \pm 0.05$ \\
\hline Tahina (Befle A.fi.) & $10.98 \pm 0.09$ \\
\hline Tahina (Manisali A.fi.) & $11.87 \pm 0.02$ \\
\hline Plain Halva (Koska A.fi.) & $8.24 \pm 0.01$ \\
\hline Plain Halva (Befle A.fi.) & $9.12 \pm 0.02$ \\
\hline PlainHalva (ManisaliA.fi) & $9.05 \pm 0.06$ \\
\hline Plain Halva (Market) & $4.97 \pm 0.01$ \\
\hline
\end{tabular}

Tahini is $100 \%$ composed of ground sesame seeds and constitutes $50 \%$ of the composition of halva by weight (Sahelian, 2007). Wen-Huey (2007) reported that the mean of total lignan contents of 14 brands of Taiwan sesame oils was $11.5 \mathrm{mg} / \mathrm{g}: 82 \%$ and $15 \%$ of lignans were sesamin and sesamolin, respectively. Additional data on the limits of the identification and quantification of sesamol in oils is needed. Therefore, a recent study gives a data set of sesamol in sesame, tahina and halva products (Table 2 and Figure 3 A-B).

With the proposed DPP method, sesamol and related lignans were effectively determined in sesame, tahina and halva samples. These abovementioned procedures provided a sufficient, reproducible and sensitive quantitative detection for lignans. A sensitive detection of these compounds in related foodstuffs can be useful for quality control analyses.

\section{REFERENCES}

Amarowicz R, Shahidi F, Pegg RB. 2001. Application of Semipreparative RP-18 HPLC for the purification of sesamin and sesamolin. J Food Lipids 8, 85-94.

Anonymous. Agriculture Structure and Production. 1999. T.C. Baflbakanl> k Devlet Istatistik Enstitüsü ,Ankara, Turkey. p:301.

AOCS.1998. Official Methods and Recommended Practices of the AOCS ( $5^{\text {th }}$ Edition, 1998), Method Number $\mathrm{Cb} 2-40$

AOAC. Official methods of analysis of the Assocation of Official Analytical Chemists., 1999, Method No.92307, AOAC: Washington D.C.
Aycan Ş. 1994. Differential Pulse Polarography (DPP). In "Polarographic and Voltammetric Techniques". Yildiz Technical University Publisment, No:293, Istanbul, 1994.

Aycan Ş,Tokusoglu Ö, Koçak S, Yildirim Z. 2003. A Novel Analytical Method for Some Heavy Metals and Essential Trace Elements in Four Micropropagated Turkish Potato (Solanum tuberosum L.) Cultivars with Deep-Fat Fried Forms and Some Commercial Potato Chips. J.Food Technol. 1, 36-41.

Budowski P. 1962. Recent research on sesamin, sesamolin, and related compounds. J.Am.Oil Chem Soc. 41, 280-285.

Fukuda Y, Osawa T, Namiki M. 1981. Antioxidants in sesame seed. Nippon Shokuhin Kogyo Gakkaishi 28, 461-464.

Kamal-Eldin A, Appelqvist LA. 1994. Variations in the compositions of sterols, tocopherols and lignans in seed oils from four sesamum species. J. Am. Oil Chem. Soc. 71, 149-156.

Kamal-Eldin A, Appelqvist LA, Yousif G. 1994. Lignan analysis in seed oils from four sesame species: comparison of different chromatographic methods. J. Am. Oil Chem. Soc. 71, 141-147.

Kaur IP, Saini A. 2000. Sesamol exhibits antimutagenic activity against oxygen species mediated mutagenicity, Mutation Research/Genetic Toxicolgy and Environmental Mutagenesis 470, 71-76.

Koçak S, Tokusoglu Ö, Aycan S. 2005. "Some heavy metal and trace essential element detection in canned vegetable foodstuffs by differential pulse polarography (DPP)". Electronic Journal of Environmental, Agricultural and Food Chemistry (EJEAFChe) 4 (2) ISSN 1579-4377.

Li-Qiong , Lu-Guanghan, Wu-Heng, Wu-Xiaogang. 1999. Determination of trace tin in foods by single-sweep polarography. Food Chemistry 64, 129-132.

Mohamed HMA, Awatif II. 1998. The use of sesame oil unsaponifiable matter as a natural antioxidant. Food Chem. 62, 269-276.

Rodrigues JA, Barros AA, Rodrigues PG. 1999. Differential pulse polarographic determination of alpha-dicarbonyl compounds in foodstuffs after derivatization with o-phenylenediamine. J. Sci. Food Agric. 47, 3219-3222.

Sahelian Ray. 2007. http://www.physicianformulas.com

Shyu YS, Hwang LS. 2002. Antioxidant activity of the crude extract of lignan glycosides from unroasted Burma black sesame meal. Food Rsch. Int. 35, 357365.

Tokusoglu Ö, Durucasu İ, Yemiş Yildirim Z. 2003a. High Performance Liquid Chromatographic Determination of Seed D-form (RRR-) Tocopherol Homologues of Sesame (Sesamum Indicum L.) Spreads: Process Effects on their Quantities. Journal of Food Technol. 1, 97-101.

Tokusoglu Ö, Yildirim Z, Yemiș F. 2003b. Some functional properties as gelation, water and oil absorption, emulsion capacity, and foaming stability of sesame seed (Sesamum Indicum L.) spreads. Turkish Journal of Field Crops. 8, 15-21.

Tokusoglu Ö, Ünal MK, Alakir. 2004a. Proximate Chemical Composition, Amino Acid and Fatty Acid Profiles of Sesame Seed Flours. .J. Food Sci. Technol. Mysore. 41, 409-412.

Tokusoglu Ö, Aycan Ş, Akalin S, Koçak S., Ersoy N. 2004b. "Simultaneous differential pulse polarographic (DPP) determination of cadmium, lead and copper in 
milk and dairy products". J. Agric. Food Chem. 52, 1795-1799.

Tokusoglu Ö, Aycan S, Serin E. 2004c. ?Tahinde Antioksidan Etkili Fenolik Sesamol Türevi Lignan Bilesikleri ile Konjuge Linoleik Asid (CLA) cis 9,trans 11 ve trans 10,cis 12 〈zomerlerinin $\mathrm{H}$ 〉 zl> Kapiler Gaz Kromatografik Yöntemlerle (GC) Saptanmas〉 ". II.nci Ulusal HPLC ve Di€er Separasyon Teknikleri Sempozyumu, Ekim07-09,Gülhane Askeri T>p Akademisi (GATA), Ankara, Turkey. Poster Presentation.

Wen-Huey Wu. 2007. The contents of lignans in commercial sesame oils of Taiwan and their changes during heating. Food Chemistry 104, 341-344.
Yoshida H, Shigezaki J, Takagi S, Kajimoto G. 1995. Variations in the composition of various acyl lipids, tocopherols and lignans in sesame seed oils roasted in a microwave oven. J. Sci. Food Agric. 68, 407-415. Yoshida H, Takagi S. 1998. Antioxidative effects of sesamol and tocopherols at various concentrations in oils during microwave heating. J. Sci. Food Agric. 79, 220-226.

* One part of this study was presented at 2003 IFT Annual Meeting,July 12-16,2003 Chicago IL,USA by Tokusoglu.

Recibido: 17/8/07 Aceptado: 3/9/08 